\title{
Housing and Welfare in Western Europe: Transformations and Challenges for the Social Rented Sector
}

\author{
Richard Ronald ${ }^{1}$ \\ (Received December 24, 2012 / Revised January 24, 2013 / Accepted January 24, 2013)
}

\begin{abstract}
In the post-war period, the mass provision of social rental housing units represented the primary means for resolving housing welfare issues across much of Western Europe. In contrast to North America, large swathes of state subsidized rental housing where built and let-out at submarket rents, both to needy as well as regular working households. By the 1980s social housing accounted for as many as four in ten homes in some contexts. Since then however, these important welfare sectors have been under attack. On the one hand, privatization policies have continued to undermine the basis of social renting with home ownership and private rental sectors advanced by policy as preferable alternatives. On the other hand, social housing providers have been restructured in order to play a more residual role in the housing market and serve more targeted groups of socially vulnerable people. This paper assesses key differences in the development of West European social housing sectors as well as recent transformations in their status that represent a challenge their sustainability. It also looks to what insights this provides for the South Korean housing context where public housing has proliferated and been increasingly diversified in recent years.
\end{abstract}

Key words: Europe, Social Housing, Public Housing, Privatization, Residualisation

\section{Introduction}

In the West European context, housing as a welfare issue came to the fore in the late-nineteenth century largely as a result of slum formation generated by intensive industrialization and urbanization. Early interventions were led, in the absence of welfare states, by charitable organizations and often took the form of social housing experiments. In the early-twentieth-century, in context of early welfare politics and the rise of the labor movement, governments became increasingly involved in improving housing conditions and providing housing for working households. This was often achieved in cooperation with private housing associations and local municipalities, normally by constructing rental units let at submarket rates to working, low-income families. In the postwar period state interventions became much deeper and the output of social rental housing reached a zenith in Europe. By the mid1980s social rented housing sectors accounted for around $20 \%$ to $39 \%$ of housing in Austria, France, Denmark, Sweden, The Netherlands and the UK (see Priemus and Dieleman, 2002). In urban contexts social housing became particularly concentrated, and in cities like Amsterdam still represents almost half the housing stock.

The postwar model has, however, come under increasing attack in recent decades and housing as a feature of public welfare provision has been transformed. The notion of housing policy itself has increasingly come under the domain of economic and other policy imperatives rather than social welfare. More critically, social housing has been reimagined and the sector restructured involving, in many cases, deregulation and deep privatization strategies. Meanwhile, the nature of social housing has become more diversified to include social forms of home ownership and hybridized in terms of finance, construction and management (Czischke, 2009; Mullins et al., 2012; Rhodes et al., 2009).

This paper attempts to deal briefly with a broad topic. The intention is to draw attention to the hazards of developing a substantial social housing sector and the challenges of sustaining it in light of the considerable expansion in South Korean public housing in recent decades. Firstly, it focuses on housing welfare in terms of different types of public and social housing. It does this initially by considering the cases of Britain and the Netherlands

1) Associate Professor, Centre for Urban Studies, University of Amsterdam, Amsterdam, The Netherlands (Corresponding author: R.Ronald@uva.nl) 
as public and social housing sectors 1 ) in these two countries have been historically strong, featuring in the development of welfare states as well as, more recently, neoliberal policy realignments. It goes on to consider diversity within the European model and different ways of approaching not-for-profit housing as a welfare service.

Secondly, it addresses recent developments in social housing sectors and the challenges they have endured. Again with an emphasis on the British and Dutch examples, the paper will illustrate three different threats. The first is the polarization of tenure, which in the UK began with the residualisation of council housing2) through the 'right to buy' policy in the 1980s. Selling to sitting tenants effectively polarized and stigmatized the sector, justifying deeper transformations in the regulation of social landlords and reducing funding for the sector despite the 1.7 million households now on social housing waiting lists. Social housing in the UK is argued to now be on the way to becoming a 'social ambulance service' rather than a 'safety net' (Fitzpatrick and Pawson 2011). The second threat is the privatization of welfare. In this case the paper addresses shifting logics among West European welfare regimes, which have increasingly turned to low-income home ownership as an alternative means to support both housing and other welfare needs (Ronald and Elsinga, 2012). Lastly, attention turns to a multifaceted threat represented by a recent EU decision on the status of housing associations (in the Netherlands). The decision has initiated reregulation on the role of Dutch housing associations as providers that influence private market conditions, which has broad implications for associations across Europe. It is effectively recasting expectations of housing associations as third sector institutions as well as the rights of low-to-middle income households to a social rental home (see Priemus and Gruis, 2011). This shift in conditions has arrived on top of existing pressures derived from the Global Financial Crisis that have already undermined the financial base of many social housing institutions.

1) In this paper social housing is a more inclusive term that implies housing where rents are not set by market criteria and allocations are made by administrative criteria (Fitzpatrick and Stephens 2008, p28). Public housing is typically, but not always social, and the term implies ownership by national or local government. Social housing providers and agencies can be either public or private, with the latter functioning typically as a non- or limited-profit company serving social objectives.

2) Council housing is the vernacular phrase used in the UK to describe public rental housing owned by local municipalities. It is often used to describe all types of social rental housing, even though most is owned or run by non-profit agencies these days. It has become somewhat stigmatized as a label in recent years.

\section{The Origins of Social Housing}

At the turn of the $20^{\text {th }}$ century the urban poor in West European cities where typically housed in cramped and unhygienic conditions, leading to calls for public interventions. In the absence of a welfare state, early housing interventions were led by philanthropic organizations rather than government agencies (see Pooley, 1993). In some contexts, such as the Netherlands, private housing associations played a particularly important role. In 1899 there were 112 such organisations nationwide with a total of 7746 dwellings (van der Schaar, 1987). The growing call for the authorities to take responsibility for living conditions, led by liberal progressives, rather than the left, helped drive a transition from a 'night-watchman state' toward a 'welfare state' in which housing featured as a pillar (Ekkers and Helderman, 2010). The 1901 Housing Act (WoningWet) was a landmark Dutch legislation as it not only defined building standards and gave responsibilities for housing to local authorities, it also provided private non-profit housing initiatives with a new formal status. As long as these approved associations worked exclusively in the interests of improvement of social housing they could receive financial incentives and access loans on favourable terms (Ouwehand and van Daalen, 2002).

Along with continued industrialisation and population growth large swathes of urban housing were built in the first half of the $20^{\text {th }}$ century in the Netherlands, driven by the activities of housing associations. In the UK too, following early initiatives (i.e. the 1890 Housing the Working Classes Act), ${ }^{3)}$ wider reaching legislation was put in place after World-War-One (1919 Housing Act) that gave local authorities responsibilities for providing housing. This usually, but not always meant the construction of subsidised rental units that rapidly overtook, in number of stock, the scale of charitable housing association provision (Merrett, 1979).

In the Netherlands, the targets of housing associations where rank and file, working households, whereas the housing needs of the very poor were considered the task of the municipal housing companies. Following an initial rush in social housing construction in the 1920s, quantitative housing shortage began to fall away and the number of Dutch housing associations levelled off (to around 1000 following a peak of 1350 in 1922) with an average stock of 150 dwellings each by the end of the 1930s. In this period,

3) The 1890 Act loosely encouraged local authorities to improve housing conditions, although by 1914 there were only around 28,000 municipal units compared to almost 50,000 provided by charitable organizations. 
subsidies for non-profit housing declined along with renewed confidence in the capacity of the market to provide affordable housing for workers, with social rental housing supporting a smaller part of the population. In the UK meanwhile, the social rental sector was establishing itself as a small but viable housing sector, occupied by largely better-off working class households (Malpass, 2005). By the 1930s, in light of a shifting economic climate, more poor working class households began to flow into the sector while market provided housing became more attractive to better-off working class families.

\subsection{Postwar Social Housing}

Social and economic conditions after World-War-Two drove an extraordinary expansion of dwellings constructed for rent at submarket prices across Western Europe. This proliferation was driven not only by massive war derived shortages, but also shifting socio-political pressures to improve public health and living conditions for workers. Government support was quite remarkable in this period. In France, for example, between 1953 and 1975 , of the 8 million units built $80 \%$ profited from government funding (Effosse, 2003). In the UK meanwhile, local authorities built $60 \%$ of all housing between 1945 and 1965 with public housing increasing from around $12 \%$ to $32 \%$ of stock by 1979 (Malpass, 2005). While considerable variety existed between countries in the finance, form and management of new social units, there was some consensus among lenders, builders, employers, governments and municipalities that facilitated the mass expansion of subsidized rental housing (Lévy-Vroelant and Reinprecht, 2008). An implicit assumption was that market arrangements could neither meet the speed of provision, nor coordinate appropriate forms of housing suitable for post-war society. Social housing was generally considered a 'merit good' and access extended.

In the Netherlands, central and local government took a more prominent role in planning, financing and allocating dwellings, with the existing housing associations considered a framework to manage the newly created stock, albeit under the direction of public agencies. By the 1970s around 170,000 new homes were being constructed annually with social rental housing constituting the largest part (with 830,000 units built between 1964 and 1970). The social housing stock thus tripled between 1950 and 1980 (see Boelhouwer, 2002). The relationship between tenants and associations also changed as the union type associations based on a coherent membership were transformed. Associations themselves were effectively supported by the state and became concerned with building housing rather than serving a constituency of tenants (van der Schaar, 1987). Nonetheless housing policies were considered successful in terms of construction rates, while quality and accessibility improved.

In the British case, post-war policy identified the need to build more rapidly and to allow for more planned developments. It also explicitly recognised the principle that every family should be housed in their own separate dwelling with access to all facilities necessary for a 'full family life' (Titmuss, 1958). Although longterm plans envisioned a more prominent role for the private sector, public rental housing construction was expedient. While public housing represented an extension of the welfare state into the sphere of housing, it is argued that production output and reviving the construction sector was the major concern and private housing policy remained unreformed (Cole and Furbey, 1994). Furthermore, public housing was not a universal right of citizenship, like other welfare state services, and access was only open to an increasingly powerful group of working-, and not middle-class households. It was nonetheless, occupied by a relatively wide income range of worker households.

In the Netherlands, on the other hand, social housing played a slightly different role and increased in scale throughout most of the second half of the twentieth century, while homeownership remained the minority tenure. Initially, public housing expansion helped solve post-war shortage issues, allowed for comprehensive planning and the revival of the construction sector. It also served the interests of a Rent-Income politics, where making real rents cheap served to keep incomes low and thereby labour costs for industry, supporting post-war economic recovery. Social housing providers in the Netherlands have been essentially 'private' non-profit institutions (especially since 1995) and thus sit outside the welfare 'state'.

Nonetheless, there are some important welfare considerations. As more than one in three Dutch people still live in sub-market rented dwellings and more than $60 \%$ of the private rental sector is still rent regulated (a combined total of almost $39 \%$ of all households), and that $11 \%$ of these households receive a housing allowance, the quality of dwelling and the size of after-rent income relies a lot on the housing system and the legacy of past and present public housing subsidies ${ }^{4}$ ). Access to urban housing, especially for younger households, has historically depended on social renting, which typically constituted a step on the housingladder for even some middle-class families. Dutch social housing has played a particular important role in the economy and society

4) Indeed the Netherlands continues to have one of the lowest poverty rates among developed nations (4.7\% of families) and a healthy GINI value (30.9 in 2007). 
and represents a fundamental means by which the state can intervene. It is thus an important part of the welfare system, rather than a feature of the welfare state.

It is difficult to locate public and social housing in West European post-war welfare states as it has served far more interests than simple welfare and fit unevenly with the logic of state provision. In the British context, whereas the National Health Service has an iconic status in the welfare state, public housing has, in the long run, been the main victim of welfare retrenchment. For Harloe (1995) social housing has expanded during particularly unusual periods in the course of $20^{\text {th }}$ century capitalism. He suggests that a mass model of social housing organized by the state has only come to the fore in exceptional periods after the world wars. However, as social and economic conditions rebalanced, a residual model has reasserted itself, with housing again becoming more market based. Considering the reliance of social rental housing in some contexts, however, Kemeny (1995) has been critical of Harloe's fatalism regarding marketization as many countries in North Western Europe have sustained commitment to housing as a social good. Meanwhile a process of maturation - as housing providers have repaid debts and established considerable real-estate assets - has bolstered the economic base of social housing institutions. Figure One illustrates how, in the Dutch case, large scale rental housing output has persisted throughout the last forty years, the vast major of which has been social. Indeed increased social rental housing output drove not only the rise in new rental housing during the 1980s, but housing production overall as the government sought to draw on the capacity of a large social sector to compensate for cycles in the private owner-occupied market.

\subsection{The Neoliberal Period}

By the late-1980s, the size of public and social rented housing sectors had already peaked in most West European countries. Starting in the late-1970s, but becoming more intensive in the last two decades, transformation in housing sectors has been radical. Specifically, in line with neoliberalization more generally, market concepts and market forms of coordination have been in the ascendancy in housing policy and among housing organisations. Recent interventions have driven privatisation and residualisation of the social rented sector, representing a shift away from the provision of housing as a collective good delivered by special purpose agencies (Rhodes and Mullins, 2009). Even in the Netherlands, which has maintained (proportionally) the largest social housing sector in Europe, regulations have been imposed on housing associations concerning how much subsidised rental housing they should provide and the range of low-income households that have access (see Gruis and Priemus, 2011). At the same time, rhetoric and policies that support the growth of home ownership have come to the fore (Aalbers, 2004). By 2010 the social sector was $32 \%$ of housing compared to $39 \%$ in 1985.

As part of this transformation Dutch housing associations were 'cut loose' as independent non-profits agencies in 1995 and construction subsidies ended (Priemus, 1996). Associations become financially independent through a 'grossing and balancing operation' (brutering) in which future subsidies for running cost for existing stock were capitalised and exchanged against the value of outstanding loans from the central government (van der Veer and Schuiling, 2005). On giving up direct control of housing associations, the task set out by the state was embedded in the

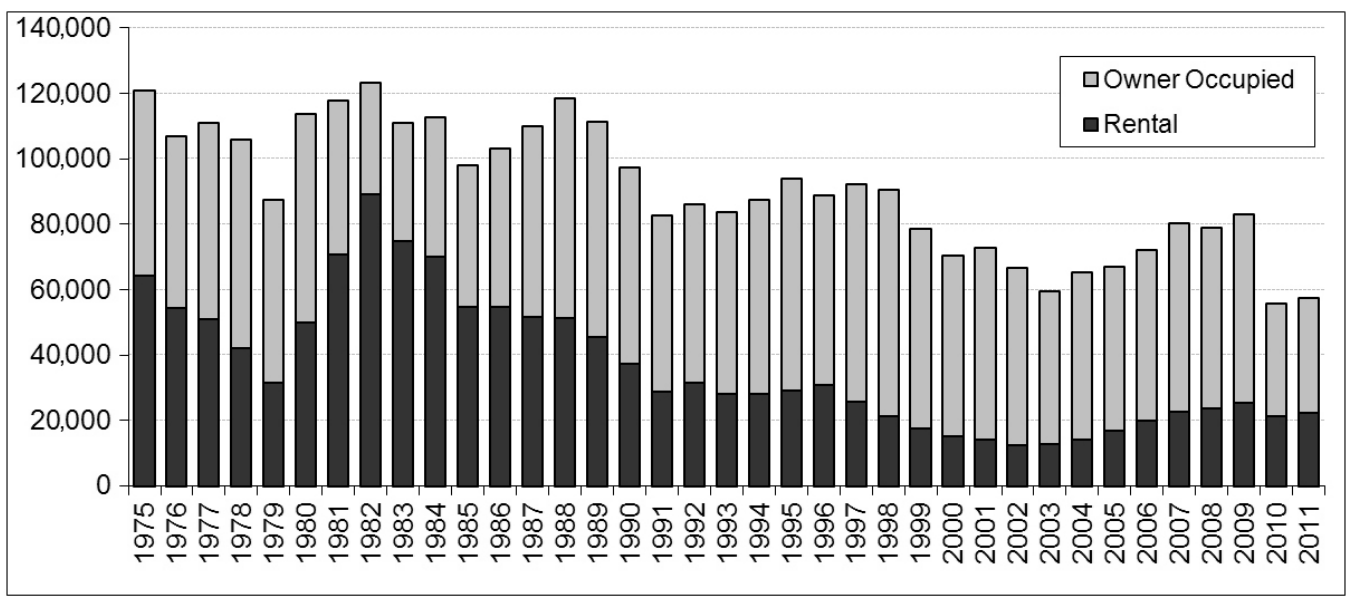

Source: CBS (2012)

Fig. 1. Housing production in the Netherlands 
Social Rented Sector Management Order, which specified the obligation to provide 'good, affordable rental housing for those unable to find a dwelling in the market'.

Essentially, the logic and practice of social housing provision was revolutionised in the 1990s and 2000s. It involved, on one hand, a critical disengagement with responsibilities for housing on the part of the government and, on the other, a kind of 'privatisation' of the social housing sector featuring more socially entrepreneurial agencies providing both low-rent units and housing for sale. The 'brutering' cost around 17 billion Euro and was realised in just one year. Housing associations were suddenly very solvent and increasingly professionalised their operations, which involved various mergers that reduced the number of associations nationally to around 400 by 2012 . A central fund for social housing was set up (CFV) that guaranteed loans for the sector (making borrowing from capital markets for social construction cheaper). At the same time, housing associations began building for the owner-occupied market, the profits from which supported a revolving fund for new social rental and urban renewal projects.

In the UK the transformation has also been drastic with the public and social rental sector shrinking from $32 \%$ in 1979 to around $18 \%$ in 2007 . This was largely achieved by selling off a large part of the public stock, owned and managed by local authorities, to sitting tenants through the 'right to buy' legislation instigated by the Thatcher government in the 1980s. More than one and a half million homes were sold in this way during the 1980s and nineties (which is similar to the number of those now on the waiting list for social housing in the UK), while little funding was reinvested in the sector. Table One illustrates the shift in tenure between 1981 and 2000. Another major transformation was the shift in ownership and management of the stock. With the increasing residualisation of 'council housing', large swathes of the remaining stock

Table 1. Housing tenure transformations in the UK

\begin{tabular}{c|c|c|c|c|c}
\hline & 1981 & 1985 & 1990 & 1995 & 2000 \\
\hline $\begin{array}{c}\text { Local authority } \\
\text { (social rented) }\end{array}$ & $30.4 \%$ & $26.8 \%$ & $22.0 \%$ & $18.6 \%$ & $14.7 \%$ \\
\hline $\begin{array}{c}\text { Housing association } \\
\text { (social rented) }\end{array}$ & $2.2 \%$ & $2.5 \%$ & $3.0 \%$ & $4.4 \%$ & $6.3 \%$ \\
\hline Owner occupied & $56.4 \%$ & $60.5 \%$ & $65.8 \%$ & $67.2 \%$ & $69.2 \%$ \\
\hline Private renting & $11.0 \%$ & $10.2 \%$ & $9.1 \%$ & $9.9 \%$ & $9.8 \%$ \\
\hline Total Stock (thousands) & 21586 & 22378 & 23476 & 24417 & 25303 \\
\hline
\end{tabular}

Source: UK Housing Finance Review (Wilcox, various years) were transferred to non-government, limited- or non-profit agencies nominated as Registered Social Landlords (RSLs). Meanwhile and number of non-government agencies known as ArmsLength Management Organisations (ALMOs) were established to manage public housing services on the municipalities' behalf (Pawson and Mullins, 2010).

The most fundamental difference in housing privatisation between the UK and the Netherlands lies in the supply function of social housing. In 2005 there were 17,200 social housing completions in England compared to 67,000 in the Netherlands (see Scanlon and Whitehead, 2007), even though the former country has more than triple the population of the latter. In recent decades the UK and Germany have stood out in terms of the declining supply role of public housing producers. In other West European nations supply levels have dropped off, but have generally been stable. The Netherlands is perhaps an exception as housing associations lead urban housing construction. In Amsterdam, the percentage of housing provided by the eight remaining housing associations still represents more than $70 \%$ of new development.

\section{Diversity in West European Social Housing}

The Netherlands and the UK in this paper so far have effectively represented a limited diversity across West European housing. They nonetheless illustrate two types of approach to housing and welfare that have become common in the housing literature for explaining divergences in the fates of social housing sectors. They contrast starkly to approaches in America where public rental housing has never really represented more than a marginal sector for the very poor in urban areas (see Goetz, 2003). In the USA housing vouchers have historically been a favored means of housing relief for low-income families and sustain their position as bottom-end consumers in a largely private market of housing.

A more significant contrast to the UK and the Netherlands is Germany, where social rental housing provision has remained low (only 5\% in 2009), whereas subsidies and controls in the rental market overall have ensured a supply of affordable rental housing for low-income groups. In particular, in return for time limited subsidies private firms build large numbers of units every year that are let at submarket rates to low-income households. When time limits expire, sub-market housing normally moves into the private rental market. As there is such a volume of movement (as many as 100,000 units a year) social prices and secure tenures tend to ensure that affordability across the market is maintained. 
The formal non-profit sector was reformed in 1989, with the real estate assets owned by municipalities transferred to private companies. Municipal housing companies and (non/ limited-profit) cooperatives constitute a large part of this private sector along with private landlords and commercial investors and developers.

As can be seen in Table Two, social housing sectors across Western Europe are diverse in sector size, as well as in terms of legal and organisational forms of social housing actors (from public bodies to non-profit agencies and cooperatives). There are also important differences in the overarching housing policy frameworks under which providers operate (Czitschke, 2009). Building on Kemeny's model (1995), it is nonetheless possible to distinguish between two key types. Universalistic approaches stem from a particular conception of social welfare which aims to provide housing of decent quality at affordable prices for the population as a whole. Within this approach housing is considered a collective responsibility and delivered by local governments or non-profit organisations. The other type is a targeted approach, which assumes that housing needs will be met

Table 2. Social rental housing in Europe (selected countries)

\begin{tabular}{l|c|c|c|c}
\hline & $\begin{array}{c}\text { Social Rental } \\
\text { as of Total } \\
\text { Housing }\end{array}$ & $\begin{array}{c}\text { \% Social } \\
\text { Rental of } \\
\text { Total Rental }\end{array}$ & $\begin{array}{c}\text { Number of } \\
\text { Social Units } \\
\text { per 1000 } \\
\text { Inhabitants }\end{array}$ & $\begin{array}{c}\text { Social Rental } \\
\text { Housing as } \\
\text { \% of New } \\
\text { Completions }\end{array}$ \\
\hline Austria & 23 & 56 & 100 & 27.5 \\
\hline Belgium & 7 & 24 & 32 & 6 \\
\hline Denmark & 19 & 51 & 95 & 22 \\
\hline Finland & 16 & 53 & 85 & 13 \\
\hline France & 17 & 44 & 86.5 & 12 \\
\hline Germany & 4.6 & 7.8 & 22.6 & 15 \\
\hline Hungary & 3.7 & 53 & 15.9 & na \\
\hline Ireland & 8.7 & 41 & na & 7 \\
\hline Italy & 5.3 & 28 & 29 & na \\
\hline Latvia & 0.4 & 2.5 & na & 1 \\
\hline Lithuania & 3 & 43 & 11.7 & na \\
\hline Luxembourg & 2 & 7 & 7.8 & na \\
\hline Netherlands & 32 & 75 & 138 & 19 \\
\hline Poland & 10 & 64 & 34.9 & 9.5 \\
\hline Portugal & 3.3 & 16 & na & na \\
\hline Romania & 2.3 & na & 8.9 & 4 \\
\hline Slovakia & 2.6 & 87 & 8.5 & 12 \\
\hline Spain & 2 & 15 & 10.9 & 16 \\
\hline Sweden & 18 & 48 & 84 & 13 \\
\hline UK & 18 & 54 & 80 & na \\
\hline & & & & \\
\hline
\end{tabular}

Source: CECODHAS, 2012 predominantly by the market. Policy prescribes that social housing is thus only extended to those for whom the market is unable to deliver. Whereas universalistic approaches are associated with Unitary systems where social housing has a market regulating role (influencing private sector rents), targeted approaches sustain Dualist housing systems where social sectors cater for vulnerable groups aside from the mainstream market.

In the countries we have discussed in detail so far, the Netherlands demonstrates a system most akin to a universalistic approach and unitary system. Germany, despite the prevalence of the private rental market ( $49 \%$ of all housing), is similar in respect the role of the subsidized part of the rental sector. The flow of public subsidies for fixed-period social units has an overall effect on the rental market in terms of supporting access and affordability for low-income households. The British system, although having a highly inclusive public housing sector until the 1980s, has historically developed a more differentiated tenure system along private/public lines. In recent decades, with the shrinking of the public sector (which, though the restructuring of management and ownership has become more a social sector) it has increasingly represented a targeted approach and a dualist system.

Transformations in the provision of social housing in each country have retained considerable path dependency, reflecting pre-existing scales of provision and frameworks of delivery, allocation and management. The trend away from government control and public forms towards market types and principles has, however, been more-or-less ubiquitous in Western Europe. Fundamentally, there has been an ascendency in more targeted approaches to social housing. Ghekiére (2007) has therefore distinguished two further sub-types within neo-liberalised versions of social housing sectors, although some countries feature elements of both. In one, housing is allocated in terms of those falling under an income ceiling (Generalist) and in the other social housing provision is for the most vulnerable (Residual). While the former follows a more traditional conception of 'social' housing, albeit to a more restricted population, the other caters for a more limited category of beneficiary. These reflect different alignments towards social housing as a feature of welfare with the former considered to have either a wider affordability or safety net function, and the latter an ambulance service.

In understanding social housing as an 'ambulance service', Fitzpatrick and Stephens (2008) point to non-European, developed nations such as the USA, Australia and Canada. There, social housing has never seriously contributed to housing supply and the sector has remained small and concentrated in terms of poverty, 
unemployment and depravation. In Canada, for example, between $58 \%$ and $70 \%$ of public and community housing allocations go to special needs cases. The ambulance service housing provides in this case is also temporary and once the 'emergency' is over, eligibility for social housing services may be withdrawn. In Europe, such limitations are rare and usually after a household has found a social dwelling, even if income increases and qualification expires, eligibility is not withdrawn.

While much better than the USA, the UK has higher levels of poverty and inequality compared to its West European neighbours and a social security system that does less to reduce inequalities arising from the labour market. Although benefits like unemployment benefit are generally low, they are comprehensive and when combined with housing allowances together act to prevent post-rent income falling below a basic minimum. It currently represents therefore more of a 'safety net' for those falling into poverty and is effectively universal. That said, recent political changes in England have provided a challenge to the security of social renters and future allocations may be explicitly granted on a temporary basis. In context of a diminished, inadequately funded social rental stock, being on a low-income may no longer guarantee any permanent right to a social dwelling, which, it is being argued in political circles, should be a service reserved for the most needy. Fitzpatrick and Pawson (2011) suggest that this may represent a shift from English welfare housing as a safety net to an ambulance service

In UK social housing, allocations since the 1970s have prioritised applicants with low incomes. Through the decades the social tenant population has become increasingly concentrated with tenants from the lowest income deciles. This development was intensified by 'right to buy', which sucked both better-off tenants and much of the better housing stock away from the tenure. In the Scandinavian countries, Germany and the Netherlands there remains far greater diversity among tenants in social housing, while social inequalities are also not so extreme as in England. Social security systems tend to compensate better for labour market inequalities and benefits are more generous. For example, in the Netherlands, unemployment benefits are set at around 70\% of the previous working wage for the first year. Thus, when combined with welfare benefits, the social rented sector goes beyond providing a 'safety-net' to foster a 'wider affordability function' (Fitzpatrick and Stephens, 2008). While the criteria are currently in flux, Dutch social housing eligibility is far broader than Britain's and the sector accommodates a far wider range of income-groups. Even following recent tighter recommendations on income criteria from the EU (Gruis and Priemus, 2009), around $40 \%$ of households qualify for social housing in the Netherlands. Within the larger social rental sectors in Western Europe, there are sometimes subsectors to be found, often described as 'very social housing' (for example in Sweden and France) with lower rents, lower income limits and less security of tenure (see Lévy-Vroelant and Reinprecht, 2008).

\section{Challenges to Welfare and Sustainable Social Housing}

Notions of housing welfare and perceptions of social housing sectors have undergone series of revisions and re-imaginings in the last century (Harloe, 1995). Transformations have caused the dynamics of public and private forms of housing to transmogrify. Various authors have focused on contributory elements to this process, which has proceeded at different paces in each context (see Priemus and Dieleman 2002; Rhodes and Mullins 2009; Cowans and Maclennan, 2008). The recent tendency has been toward an erosion of social and, in particular, public housing sectors in size, the socioeconomic diversity of occupants, funding and supply. Social housing sectors are unlikely to disappear, but are undeniably on the defensive. As was established in the introduction and is explored in this section, challenges can be conceptualized (although this is not an exhaustive framework) along three main latitudes: 1) the status, or polarization, of tenure, 2) conceptions of housing as a welfare good or service and, 3) the position of housing associations.

\subsection{The polarization of tenure}

One of the greatest challenges to social housing is to sustain its status vis-à-vis other housing tenures and types. With the residualisation of social housing supply there has been an increasing concentration of extremely poor, unemployed and special needs groups in social dwellings. Social housing is thus being - although there is considerable inter-country variation gradually stigmatised and marginalised. For example, post-war council estates in England have become enmeshed with end of history discourses regarding planning mistakes, unpopular housing design and problems of social segregation. 'Council housing' has become a byword in the media and neoliberal discourses for concentrations of crime and depravation that reflect the 'failures' of (big) government and the application of market rules. In France too, urban social housing estates are no longer seen as a triumph of post-war modernist architecture, but often the location 
of dangerous groups of impoverished people and the site of racial unrest, especially among disenfranchised French-Arab youth.

Critiques of social housing have largely focused on design, scale, management and maintenance arrangements on mass housing estates - seen as somehow the cause of segregation and neighbourhood decline - even though estates are not typical of the sector. Furthermore, while design mistakes were made and socio-demographic changes have had an impact (with growing segregation of migrant communities), problems among many social housing estates have been the outcome of declining investment and the shift in subsidies to other sectors (see Forrest and Murie, 1988; Musterd et al., 2010). The vast majority of post-war social housing developments were popular when they were first inhabited and represented a remarkable improvement in housing conditions. Indeed, British social housing helped radically improve the number of lower-income households with inside toilets, central heating and other basic amenities in their homes. In recent decades however, on top of sector disinvestment, the transformation of swathes of English public housing through stock transfers or sales to sitting tenants has helped commodify perceptions of housing stock (now seen as a market rather than merit good) and individual housing preferences. Meanwhile, the loss of the more desirable dwellings to privatization and the exodus of more socially mobile tenants through 'right-to-buy' contributed to the concentration of poor and socially excluded households in the social sector, reinforcing its stigmatization (Hills, 2007). One telling statistic is that in 1962 only $11 \%$ of households in council housing in England had no earned income while in 2003 the figure was 65\% (Holmans 2005).

Malpass and Victory point out that social housing used to be 'predominantly the tenure of the relatively well-off within the working class' (2010, p5). However, the re-structuring of the sector has helped confirm a status change in social rental housing from a public good for all citizens to a more contingent service for the very poor, excluded or vulnerable. Lévy-Vroelant and Reinprecht (2008) argue that in European policy language the notion of 'vulnerability' has become embedded in regard to social sectors. In the case of subsidised housing it has specified that only those with 'special needs' qualify as 'worthy' recipients. Within the EU this designation covers immigrants, the disabled, frail elderly people, single-parent households, the unemployed and victims of wars and catastrophes. The decline in regular working households and the concentration of the poor and marginal has helped reinforce the contraction of social housing provision further. It has, moreover, legitimated transfers of ownership to non-governmental corporations, further sell-offs and the deeper application of market principles to social agencies and public services.

Although the focus so far has been the UK, looking across Europe, it is evident that the residualisation and neo-liberalisation of social housing, while less pronounced, is undermining not only the economic and material base, but also the perceptual/reputational base of social housing more universally. Even in the Netherlands, some post-war and even 1970s social housing developments are being pulled down, and neighbourhoods associated with social renting, redeveloped. In many contexts, social tenures that were once popular among a broad class of occupants have become heavily stigmatised. In formal and informal discourses, social renters are often not considered full or competent citizens and their dwellings treated as inferior to the real 'homes' or owneroccupiers (Gurney, 1999). Among low-income households social renting no longer necessarily represents a superior form of tenure to private renting, as it once did. In fact, many countries have also shifted towards demand-side subsidies like housing benefits and vouchers that can be used for private rental property5). Meanwhile, home-buying has become a strong, albeit riskier preference for low-income households, although most have been squeezed out of this market in recent years. The challenge for governments and policy makers is to find a way to reverse this trend and rehabilitate social rental housing as a normal and viable tenure. While states have often contributed to the polarisation of tenure conditions and perceptions through policy and rhetoric, there is a sustained need for social housing. In recent years societies have become even more socioeconomically unequal and the real demand for affordable rental housing has intensified.

\subsection{The Privatization of welfare}

The polarization of tenure largely reflects a shifting logic among West European welfare regimes, which have increasingly turned to low-income home ownership as an alternative means to support both housing and other welfare needs (Ronald and Elsinga, 2012). For Malpass and Victory (2010), while council housing reflected an organizational model of service delivery under the post-war welfare state and operated outside the market, the model that has emerged since the 1970 s reflects a fundamental neo-

5) Gray and McAnulty (2008) identify, for example, explicit programmes in the UK and Ireland that seek to enhance the role of the private rental sector to house the homeless and vulnerable households, leading to more residual users in the private sector. 
liberal logic and the crisis of Keynesianism. Malpass and Victory explain developments in social housing in terms of processes of 'modernisation' in which public services, sustained by a discourse of decline, have been rolled back or undermined. 'The New Right approach prescribed a doctrinaire preference for privatization and marketization as remedies for perceived problems within public services' (p8).

Under more neo-liberalized manifestations of welfare states, the answer to housing low-income housing has been reconstituted, but not as an issue of what the state can do, but rather as a question of affordability and allowing the market to do its work. With social housing and high cost demand insensitive public services posed as the problem, home ownership has been increasingly promoted as the solution. Governments thus rolled out grand targets for increased home ownership participation in the early 2000s. In the UK, the Blair government aspired to reach $75 \%$ home ownership by 2015 and in the Netherlands the 'Mensen Wensen Wonen' memoranda of 2000 explicitly stated a desired increase from $51 \%$ to $60 \%$ home ownership by 2010 (see Aalbers, 2004).

Consequently, governments have worked on ways of getting better-off tenants out of their social units and into an owneroccupied 'home' (see Ronald, 2008). Such schemes are diverse across Europe. The simplest method has been to give social dwellers the option to buy their current dwelling or another vacant unit. Such schemes dominate in Britain and Ireland, but are also being piloted in the Netherlands and elsewhere. Another approach that came to the fore during the latest house price bubble (which frustrated government attempts to expand lowincome owner-occupation) was shared ownership schemes. In the UK the dominant form has been HomeBuy and in the Netherlands, Woongarant. In the former purchasers buy at least $25 \%$ of a newly built home, and pay rent on the rest. Public agencies remain involved, with the Housing Communities Agency or the housing association holding the remaining share. When occupants can afford, they are expected to buy the remaining shares in the property. The latest initiatives (HomeBuy Direct) involve private developers together with the government holding an equity loan on $30 \%$ of the property so that the purchaser only needs to pay a mortgage on $70 \%$ of the value. In the Dutch version (Woongarant, 2012) housing associations are both developers and the share owner, and retain the first option to buy back the property. It is essentially a less market open but also less risky approach.

Despite reduced spending on direct housing provision, especially welfare housing, governments have not necessarily reduced spending on supporting housing needs. Indeed, increasing funds have gone towards housing affordability programs and indirect measures such as tax subsidies for developers and mortgage holders. For example, in the Netherlands it is estimated that Mortgage Interest Tax Relief, which is fully deductible at the top income-tax rate of $52 \%$, costs the state around 14 billion euros a year compared to a housing allowance bill of around three billion (Conijn, 2008). Considering Dutch housing associations are self-funding, this represents a subsidy for homeowners of more than fourfold that for low-income renters. It is also a subsidy that benefits those with the biggest houses and debts most, and has increased in the government budget as house price and home ownership rates have increased. Essentially, the shift in the logic of housing policy represents a shift in support from low-income households in sub-market rental housing to low and middle-income households in the private market.

The current logic of housing welfare is far removed from post-war versions. Public provision for the needy has been shrunk to a more basic (safety net) service, while the housing sector has increasingly been looked to as a means to stimulate the economy more broadly, with deregulation of the market a means to achieve this. Housing policy has come to be regarded more as economic policy in the neoliberal era, with low-income households best served by market housing. There is also a different logic implied in the provision of welfare as the state has moved away from traditional Keynesian approaches to wealth transfers. This represents a shift towards 'asset-based' forms of welfare in which individual housing wealth accrued over the life-course can compensate for diminishing public resources (Doling and Ronald, 2010). Encouraging lower income people to buy their own homes presents a means to encourage self-reliance and build up individual welfare capacity (in the form of property equity) in place of an expensive and bureaucratic welfare state. Western welfare regimes are arguably adopting forms of 'privatized Keynesianism' in which households manage between borrowing, saving and drawing upon their assets in response to changing economic and welfare pressures (Crouch, 2009). In the post-crisis era, austerity measures may intensify further the necessity for individuals and families to draw on housing assets in order to cope with volatile conditions.

Essentially, the shift in the logic of welfare housing to the focus on home ownership and support of market housing represents another challenge to social housing sectors. In order to achieve a more sustainable housing system and greater social equity, a greater balance needs to be achieved between different 
housing tenures. A stronger social rental sector does not necessarily represent a challenge to the market, and as the Dutch case has shown in the 1980s, it can assist the state in coping with market volatility. Where social rental sectors are larger and more attractive, fewer vulnerable households are drawn into highly indebted home purchases. Since the Global Financial Crisis, rates of home possessions have remained relatively low in the Netherlands. Meanwhile poorer households have been less squeezed as the vast majority still dwells in the social rental sector with secure tenures and low-rents (Ronald and Dol, 2011). In the UK by contrast, home ownership is the majority tenure among low-income households, who are therefore more economically vulnerable (Burrows, 2003).

\subsection{The Status of Housing Associations}

Neoliberal housing market restructuring has resulted in significant reorientation in the organisations that build and manage social housing. At the macro-level, there has been a substantial shift away from public ownership and control, while at the micro-level, social housing agencies have been transformed. This has featured the reform of internal management arrangements, intensified relationships with external private sector organisations (through partnerships or competition), and the management of these relationships through competition based regulations (Rhodes and Mullins, 2009 p112). At the same time, the withdrawal of direct state provision in various welfare fields has led to increasing pressures on social landlords to become more 'socially entrepreneurial'. Essentially, governments have asked more of the sector. Many have become more hybridised, providing not only housing, but also social services such as community development, employment generation, youth projects, etc. (Czischke et al., 2010). Many European housing associations have been transformed from civil service like bureaucracies to multi-facing and multifaceted agencies that combine features third sector, state and commercial organisations with competing social and market logics.

With this transformation and greater engagement with the market, the status of housing associations as non-profit agencies has come into question. In the last few years, this challenge has become a legal contestation, the resolution to which is changing the face of social housing in the Netherlands and is likely to affect other member states in the future.

Following the 1995 brutering, Dutch housing associations became increasingly involved in neighbourhood renewal and investment projects, with budgets sustained by revolving funds derived from building properties for sale in the private market. As a social agency, associations also benefited from exclusion from tax requirements. They also could acquire land in special deals with local authorities as well as borrow from the private capital market on special terms thanks to the CFV (see Elsinga et al, 2008). In light of these privileges, in the mid-2000s market sector interests complained formally to National and European governments. While the EU has no competency on housing policy, Article $87(1)$ of the EC treaty states that any aid granted by a member state that distorts competition is incompatible with the common market. Subsequently, in 2005, the EU Commissioner for Competition sent a letter to the Dutch Ministry of Housing (VROM) complaining of unfair competition in the Dutch housing market.

The claim was that the sector was too large compared to the number of low-income households and that there was no clear separation between public and private activities. There was subsequently much discussion of the competitive status of housing associations and their status as social or commercial entities. The policy proposals that emerged have attempted to make social housing policy 'Europe proof'. Precise definitions on social allocations were set out, while cross subsidization from social activities for commercial, non-social ones were to be prohibited. The rent or sale of dwellings with unregulated rents, and activities in renovation and construction in this area were to be regarded as being in direct competition with the open market. The advantages of CFV support were to be limited to social activities only, and commercial activities were to become the subject of corporate tax. In return the EU would continue to recognise Dutch housing associations as social agencies.

From January 2011 two new important measures were added. First, $90 \%$ of lettings of social rental units that become empty have to go to households with less than 34.085 Euro annual income. Any association not reaching this target will lose state support (i.e. CFV supported loans). The remaining $10 \%$ of units can be re-let on the basis of social priorities other than income (Gruis and Priemus, 2011). This, however, represents a problem for the 650,000 households whose income is too high to qualify for a social unit and too low for a mortgage on a similar market property. Secondly, activities eligible for state support have been limited to those of a 'general economic purpose': construction of rental dwellings for low-income households; constructing and renting real estate for social purposes; providing living and care facilities.

A new centre-right coalition came to power in 2010 that explicitly stated a concern with the stimulation of private rented 
and owner-occupied housing, and set about imposing even tighter conditions for the social sector. There was also the intention to shift some of the responsibilities for housing allowance from the state to housing associations. The cabinet proposed that housing associations collectively contribute 760 million Euro p.a. (around 250 euro per dwelling) starting from 2014. They government also argued for the rents of sitting tenants with annual incomes above 43,000 Euro in social housing to rise 5\% above inflation rates per year in order to counteract skewedness in the distribution of social housing. This has been scheduled to begin in 2012, although the lack of data among housing association concerning the income of longer-term tenants is limited or nonexistent. There have also been measures imposed on areas with housing scarcity in order to allow higher rent setting. Finally, the Ministry of Housing (VROM) has been broken up with responsibilities assigned to other Ministries.

The new coalition government elected in 2012 looks unlikely to reverse the trend established under the previous cabinet. Meanwhile, the EU decision on the status of Dutch housing associations is having monumental outcomes for the social housing sector. Housing associations, which have been the backbone of the housing system, are now reassessing their position and it appears that conditions for social tenants are likely to change significantly in the coming years. What happens in the Netherlands is likely to have consequences for how social housing providers are seen across the EU. Many will have to readdress their position in the market and are likely to focus more on the housing needs of low-income households rather than community housing and social needs.

\section{Conclusion}

In contrast to the European context, in the last few decades, public housing output in South Korea has been remarkable with the sector growing rapidly. Moreover, this is a highly complex sector providing different types of subsidized housing for different target groups. Permanent public rental housing, for example, has been developed since 1989 for very low-income and special needs households, while more recently, diverse categories of public housing, often with fixed-tenure periods, have been produced for low- to moderate-income households (see Ha, 2004; Park, 2007, Lee and Ronald, 2012). It seems that social housing has become a priority in South Korean policy frameworks and has aligned with the expansion of welfare state services more generally (see Kwon, 2003).
Clearly, it is difficult to consider welfare housing in Western Europe as a basis for understanding what is going on in South Korea. Indeed, it seems that more centralised coordination has been important the advance of the public housing sector here. Meanwhile government agencies do not seem to be being dictated to by a neoliberal agenda and the relentless logic of the market. In addition, while there are some comparisons, it is apparent that South Korea is following a quite distinct housing and welfare system pathway in respect to other developed East Asian Nations.

Nonetheless, there are perhaps some insights that can be drawn from the European case. In particular, various lessons can be learned about sustaining a tenure balance and ensuring that social rental housing does not become stigmatised and social renters marginalised. The UK in recent decades arguably demonstrates many of the dangers of ill-considered privatisation strategies and policy mistakes in the social sector that have undermined housing conditions overall. 'Right to buy' policy has often been presented as a success story and in many respects had positive outcomes for many low-income households. However, it initiated and sustained a process of residualisation and polarisation in the housing market. The social rental sector is now possibly becoming, especially under the current administration, an ambulance service. A strong social housing sector, as seen in the case of the Netherlands, can contribute to the stability and equity of the housing market overall. Germany also provides some insights in this regard. A major concern now is the forced reorientation of the sector across Europe following the impact of the application of EU competition policy in the Netherlands.

Notwithstanding challenges to sustaining European social housing sectors, what remains evident is that having a large and good quality social sector increases the quality of housing overall and can be directly correlated with national differences in welfare and wellbeing standards. Investing in housing as a welfare sector has undeniably improved conditions in the short- and long-term for low-income working households and provided an institutional framework with which to deal with market imbalances and inequalities. In the present global crisis, considerable financial pressure has come to bear on housing associations and other welfare housing providers. Nonetheless, considering the continued demand for housing and the squeeze on lower-income households, we can expect that housing associations will survive, albeit in more hybridised forms that depart radically in their role and orientation from their post-war forebears. 


\section{Acknowledgements}

Richard Ronald's work is supported by the European Research Council [ERC Starting Grant HOUWEL, Grant Agreement No. 283881]. He would also like to thank the Land and Housing Institute, who initially invited him to write this piece as a keynote address at the 2012 LH International Conference.

\section{References}

1. Aalbers, M. B. (2004), "Promoting home ownership in a socialrented city: policies, practices and pitfalls", Housing Studies, 19(3): $483 \sim 495$.

2. Boelhouwer, P. J. (2002), "Trends in Dutch housing policy and the shifting position of the social rented sector", Urban Studies, 39(2): $219 \sim 235$.

3. Burrows, R. (2003), Poverty and Home Ownership in Contemporary Britain, Bristol, Policy Press.

4. CECODHAS (2012), Housing Europe Review, Brussels, The Federation for Public, Cooperative and Social Housing, http://www. housingeurope.eu/www.housingeurope.eu/uploads/file_HER $\% 20$ 2012\%20EN\%20web2_1.pdf.

5. Conijn, J. (2008), Subsidiering van de woonconsumptie: een zinloos schip van bijleg, in F. J. H Don (ed), Agenda voor de woningmarkt, The Hague, Koninklijke Vereniging voor de Stathuishoudkunde.

6. Cowans, J. and D. Maclennan (2008), Visions for Social Housing: International Perspectives, London, Smith Institute.

7. Crouch, C. (2009), "Privatized Keynesianism: an unacknowledged policy regime", British Journal of Politics and International Relations, 11(3): 382 399 .

8. Czischke, D. (2009), "Managing social rental housing in the EU: A comparative study", European Journal of Housing Policy, 8(2): 121 151.

9. Czischke, D. K., V. H. Gruis and D. W. Mullins (2010), "Conceptualizing social enterprise in housing organisations", Urban dynamics and housing change ENHR Conference Paper, Istanbul.

10. Doling, J. (1999), "Housing policies and the little tigers: How do they compare with the other industrialised countries", Housing Studies, 14(2): 229 250.

11. Doling, J. and J. Ford (2007), “A Union of Home Owners”, Editorial, European Journal of Housing and Planning, 7(2): 113 127.

12. Doling, J. and R. Ronald (2010), "Housing and asset based welfare", Journal of Housing and the Built Environment, 25(2): 165 173.

13. Doling, J. and R. Ronald (2010), "Property-based welfare and European homeowners: how would housing perform as a pension?", Journal of Housing and the Built Environment, 25(2): 227 241.

14. Effosse, S. (2003), L'invention du logement aide, CHEFF editions, Paris.

15. Ekkers, P. and J. K. Helderman (2010), Van Volkshuisvesting naar woonbeleid, SDU Press, Den Haag.

16. Elsinga, M, M. Haffner and H. van der Heijden (2008), "Threats to the Dutch unitary rental market", European Journal of Housing
Policy, 8(1): $21 \sim 37$.

17. Forrest, R and A. Murie (1988), Selling the Welfare State: The Privatisation of Public Housing, London, Routledge.

18. Fitzpatrick, S. and H. Pawson (2011), Security of Tenure in social housing: an international review, London, Shelter.

19. Fitzpatrick, S. and M. Stephens (2008), The Future of Social Housing, London, Shelter.

20. Ghekiére, L. (2007), Le développement du logement social dans l'Union Européenne. Quand l'intérét général rencontre l'intérét communautaire CECODHAS-USH-Dexia, Dexia Editions, Paris.

21. Goetz, E. G. (2003), Clearing the Way: Deconcentrating the Poor in Urban America. Washington, D.C., The Urban Institute Press.

22. Gurney, C. (1999b), "Pride and prejudice: discourses of normalisation in private and public accounts of home ownership", Housing Studies, 14(2): $163 \sim 183$.

23. Gray, P. and U. McAnulty (2008), "The increased role of the private rented sector in catering for low-income groups in Northern Ireland", European Journal of Housing Policy, 8(4): 361 377.

24. Ha, S. K. (2004), Housing Policy and Practice in Korea, Seoul, Pakyoungsa.

25. Harloe, M. (1995), The people's home? Social rented housing in Europe \& America, Oxford, Blackwell.

26. Hills, J. (2007), Ends and Means: The future roles of social housing in England, London, Centre for the Analysis of Social Exclusion.

27. Holmans, A. (2005), The Context of Housing Policy since 1975, Statistical Time Series with Commentary, London, Office of the Deputy Prime Minister.

28. Kemeny, J. (1995), From Public Housing to the Social Market: Rental Policy Strategies in Comparative Perspective, London, Routledge.

29. Kwon, H. J. (2003), Advocacy coalitions and the politics of welfare in Korea after the economic crisis, Policy and Politics, 31(1): 69 83.

30. Lee, H. and R. Ronald (2012) "Expansion, diversification, and hybridization in Korean public housing", Housing Studies, 27(4): $495 \sim 513$.

31. Levy-Vroelant, C. and C. Reinprecht (2008), Housing the poor in Paris and Vienna: The changing understanding of 'social', in $\mathrm{K}$. Scanlon and C. Whitehead (eds), Social Housing in Europe II. A Review of Policies and Outcomes, LSE Press, London.

32. Malpass, P. (2005), Housing and the Welfare State, Basingstoke, Palgrave Macmillan

33. Malpass, P. and C. Victory (2010), "The modernisation of social housing in England", International Journal of Housing Policy, 10(1).

34. Merrett, S. (1979), State Housing in Britain, London, Routledge and Kegan Paul.

35. Musterd, S, R. van Kempen and R. Rowlands (2010), "Mass Housing Estates on Different Tracks, in R. Rowlands, S. Musterd and R. van Kempen (eds)", Mass Housing in Europe: Multiple Faces of Development, Change and Response, Basingstoke, Palgrave Macmillan.

36. Mullins, D., D. Czischke and G. van Bortel (2012), "Exploring the Meaning of Hybridity and Social Enterprise in Housing Organizations", Housing Studies 27(4): 405 417. 
37. Ouwehand, A., G. van Daalen (2002), Dutch Housing Associations. A Model for Social Housing, Delft, Delft University Press.

38. Pawson, H. and D. Mullins (2010), After Council Housing: Britain's New Social Landlords, Basingstoke, Palgrave Macmillan.

39. Park, S. Y. (2007), "The state of housing policy in Korea, in: R. Groves", A. Murie and C. Watson (Eds), Housing and the New Welfare State: Perspectives from East Asia and Europe, Aldershot: Ashgate.

40. Priemus, H. (1996), "Recent changes in the social rented sector in the Netherlands", Urban Studies, 33(10): 1891 1908.

41. Priemus, H. and F. Dieleman (2002), "Social housing policy in the European Union: past, present and perspectives", Urban Studies 39(2): $191 \sim 200$.

42. Priemus, H. and V. Gruis (2011), "Social housing and illegal state aid: The Agreement between European commission and Dutch government", International Journal of Housing Policy, 11(1): 89 104.

43. Rhodes, M. L. and D. Mullins (2009), "Market concepts, coordination mechanisms and new actors in social housing", International Journal of Housing Policy, 9(2): $107 \sim 119$.

44. Ronald, R. (2008), The Ideology of Home Ownership: Homeowner Societies and the role of Housing, Basingstoke, Palgrave Macmillan.

45. Ronald, R. and K. Dol (2011), "Housing in the Netherlands before and after the global financial crisis", In R. Forrest \& M.N. Yip (eds),
Housing Markets and the Global Financial Crisis. Cheltenham: Edward Elgar.

46. Ronald, R. and J. Doling (2010), "Shifting East Asian Approaches to Home Ownership and the Housing Welfare Pillar", International Journal of Housing Policy, 10(3): 233 254.

47. Ronald, R. and M. Elsinga (2012), Beyond Home Ownership: Housing Welfare and Society, London and New York, Routledge.

48. Ronald, R. and M. Y. Jin (2010), "Home ownership in South Korea: examining sector underdevelopment”, Urban Studies, 47(11): 2367 2388.

49. Scanlon, K. and C. Whitehead (2007), Social Housing in Europe, London, LSE Press.

50. Titmuss, R. (1958) Essays on the Welfare State, London, Allen and Unwin.

51. van der Schaar, Jan (1987), Groei en bloei van het Nederlandse volkshuisvestingsbeleid, Delft, Delft University Press.

52. van Gent, W. P. C., S. Musterd and W. J. M. Ostendorf(2009), "Bridging the social divide? Contemporary Dutch neighbourhood policy”, Journal of Housing and the Built Environment, 24(3): 357 368.

53. van der Veer, J. and D. Schuiling (2005), "The Amsterdam housing market and the role of housing associations", Journal of Housing and the Built Environment, 20: 167 181.

54. Wilcox, S. (2012), UK Housing Finance Review, http://www.york. ac.uk/res/ukhr/index.htm .

55. Woongarant (2012), http://www.woongarant.nl/. 